\title{
Mineralogy and geochemistry of hydrothermal kaolins from the Adelita mine, Patagonia (Argentina); relation to other mineralization in the area
}

\author{
L. E. GRECCO ${ }^{1,2}, \mathrm{~S} \cdot \mathrm{A} \cdot \mathrm{MARFIL}^{1,3, *}$ AND P. J. MAIZA ${ }^{1,2}$ \\ ${ }^{1}$ Department of Geology, INGEOSUR, Universidad Nacional del Sur, San Juan 670, 8000 Bahía Blanca, Argentina, \\ ${ }^{2}$ Researcher at CONICET, Argentina, and ${ }^{3}$ Researcher at CIC of the Province of Buenos Aires, Argentina
}

(Received 28 October 2011; revised 16 December 2011; Editor: John Adams)

\begin{abstract}
The kaolin deposit at the Adelita mine, located in the province of Río Negro (Patagonia, Argentina), was studied. Petrographic studies on thin sections and chemical analyses of major, minor and trace elements on bulk samples were carried out. The kaolin content of the rock ranges from $31 \%$ to $65 \%$. The mineralogy of the working front, which is about $45 \mathrm{~m}$ thick, varies from the upper zone, where the rock is strongly silicified, stained with iron oxides and carbonated, grading downwards to a kaolinized zone, with a quartz-kaolinite-dickite assemblage with relict lithic particles and a smaller amount of iron oxides, and ending in the deepest zone where dickite, alunite, diaspore, quartz and scarce associated kaolinite occur.

The kaolin mineralogy was determined by SEM, XRD, DTA-TG, IR and $\delta^{18} \mathrm{O}$ and $\delta \mathrm{D}$ isotope analyses. The $\mathrm{S}, \mathrm{Ba}$ and $\mathrm{Sr}$ contents are enriched during hydrothermal alteration, whereas $\mathrm{Cr}, \mathrm{Nb}, \mathrm{Ti}$ and lanthanide elements are concentrated mainly during weathering. The $(\mathrm{Ba}+\mathrm{Sr})$ concentrations in the samples studied vary between 600 and $6000 \mathrm{ppm}$ and $(\mathrm{Ce}+\mathrm{Y}+\mathrm{La})$ between 2 and $150 \mathrm{ppm}$; $(\mathrm{Cr}+\mathrm{Nb})$ remains constant for all the samples, whereas $\left(\mathrm{TiO}_{2}+\mathrm{Fe}_{2} \mathrm{O}_{3}\right)$ is below $0.3 \%$. In the hypogene deposits $\mathrm{P}_{2} \mathrm{O}_{5}$ is also more abundant and increases with the degree of alteration. Chondritenormalized rare earth element diagram shows a marked enrichment in LREE relative to HREE, with negative europium anomalies and $\mathrm{d}^{18} \mathrm{O}$ values range between $3.8 \%$ and $7.7 \%$ and $\delta \mathrm{D}$ between $-123 \%$ and $-103 \%$, suggesting that kaolin formed from the hydrothermal alteration of rhyolitic tuffs.
\end{abstract}

KEYwORDS: geochemistry, mineralogy, kaolinite, dickite, Argentina.

The mobility of major, minor and REE during alteration processes has been used by different authors to determine the origin of kaolin deposits. (Gouveia et al., 1993; Dill et al., 1997, 2000; Galán et al., 2007; Pandarinath et al., 2008, among others). Terakado \& Fujitani (1998) studied REE

* E-mail: smarfil@uns.edu.ar

DOI: 10.1180/claymin.2012.047.1.11 and other trace elements in silicastones to examine the behaviour of trace elements in the acidic hydrothermal alteration of silicic volcanic rocks. They found that most of the elements, such as $\mathrm{Na}$, $\mathrm{Fe}, \mathrm{Ba}$ and $L R E E$, were leached from the silicastones, while HREE, Th, $\mathrm{Hf}$ and $\mathrm{Zr}$ were retained in the rocks, even under strongly acidic hydrothermal processes. Dill et al. (1997) used the relationships $\mathrm{Ba}+\mathrm{Sr}$ vs. $\mathrm{Ce}+\mathrm{Y}+\mathrm{La}, \mathrm{TiO}_{2}+$ $\mathrm{Fe}_{2} \mathrm{O}_{3}$ vs. $\mathrm{Cr}+\mathrm{Nb}$ and $\mathrm{Zr} v s$. $\mathrm{TiO}_{2}$ in kaolinites to discriminate between hypogene and supergene 
kaolinization processes. The APS-bearing argillaceous zones that formed during supergene processes are significantly enriched in $R E E$ relative to hypogene equivalents (Dill et al., 2000).

Pandarinath et al. (2008) studied the effects of hydrothermal alteration on major, rare-earth, and other trace-element concentrations in rhyolitic rocks of the Los Azufres geothermal field, Mexico. They concluded that the hydrothermal alteration resulted in a decrease in $\mathrm{MnO}, \mathrm{P}_{2} \mathrm{O}_{5}, \mathrm{Ta}, \mathrm{Rb} / \mathrm{Zr}$ and $\mathrm{Rb} / \mathrm{Nb}$, and an increase in $\mathrm{Zr}, \mathrm{Nb}$ and $\mathrm{Nb} / \mathrm{Y}$. The greater variations of $\mathrm{Y}, \mathrm{Ce}, \mathrm{Pr}, \mathrm{Nd}, \mathrm{Sm}, \mathrm{Lu}$ and $\mathrm{Pb}$ in altered rocks are probably due to hydrothermal processes, whereas smaller variations of $\mathrm{CaO}, \mathrm{Sr}$, $\mathrm{Rb} / \mathrm{Sr}$ and $\mathrm{Rb} / \mathrm{Ba}$ in altered rocks suggest that these processes led to more uniform chemical rock compositions. The concentrations of REE were not significantly different in fresh and altered rhyolitic rocks, which implies that either these elements remained immobile or were reincorporated into secondary minerals during the hydrothermal alteration of the rhyolitic rocks.

Papoulis \& Tsolis-Katagas (2008) studied kaolin deposits in the western and southern parts of Limnos Island, northeast Aegean Sea, Greece, and they found two types of hydrothermal alteration zones: smectite-illite-halloysite and kaolinitedickite-rich zones. Mineral assemblages reveal that temperatures ranged from $<100^{\circ} \mathrm{C}$ (smectite-rich and halloysite-rich zones) to $\sim 270^{\circ} \mathrm{C}$ (kaolinitedickite-rich zones). Limited supergene alteration was observed in the less hydrothermally altered rocks of the illite-rich zones as suggested by the presence of jarosite and pyrite. The development of the various assemblages depends not only on the temperature and composition of the hydrothermal fluids but also on the distance of the rock from the fault or the channel of the ascending hydrothermal fluids. Papoulis et al. (2004) used the $\mathrm{K}$ and $\mathrm{Na}$ content in a kaolin deposit from Greece to measure the degree of alteration of primary rocks. The positive correlation between $\mathrm{Al}_{2} \mathrm{O}_{3}$ and LOI and the large negative loadings between $\mathrm{SiO}_{2}-\mathrm{Al}_{2} \mathrm{O}_{3}$ and $\mathrm{SiO}_{2}$-LOI indicate that $\mathrm{LOI}$ and $\mathrm{Al}_{2} \mathrm{O}_{3}$ contents increase in the more altered samples.

Ece et al. (2008) studied acid-sulphate hydrothermal alteration in andesitic tuffs in the Biga Peninsula (Turkey) and concluded that changes in the chemical composition of geothermal waters through time, and the chemistry of the intermediate products in clay deposits, also control the formation of alunite.

\section{STUDIED AREA}

In Patagonia, Argentina (Provinces of Río Negro, Chubut and Santa Cruz), there is a large number of kaolin deposits. Some of them cover a large area, such as the valley of the Chubut River (Cravero \& Domínguez, 2001), of residual and sedimentary origin, and others, which extend over a smaller area, are related to hydrothermal alteration processes in the provinces of Río Negro and Chubut. They all formed from the alteration of volcanic rocks, especially rhyolitic tuffs.

Geologically, the study area is characterized by the presence of a set of volcanic rocks and tuffs with minor clastic sediments that overlie a basement of Mesozoic age, essentially composed of granites. At the base, the volcanic complex, which is composed of andesites, is known as the Vera Formation. This complex is followed by a succession of sandstone tuffs, rich in fossil plants (Dicrodium Flora Formation) and finally by a suite of ignimbritic tuffs and flows known as the Sierra Colorada Formation, deposited at the top of the series. The age of this volcano-sedimentary complex ranges from Triassic to Middle Jurassic. Kaolinite deposits are enclosed in rhyolitic tuffs of the Sierra Colorada Formation (Labudía \& Bjerg, 2001). An important silicification, developed at the top of the formation, seems to have protected the altered areas from erosion processes giving rise to smooth elevations in the landscape.

Maiza (1972) studied several kaolin deposits in the province of Río Negro that are enclosed in highly altered rhyolitic tuffs of the Sierra Colorada Formation. The texture varies and locally becomes ignimbritic. This formation has interlayers of rhyolites and rhyolitic tuffs. These deposits are of hydrothermal origin where the main ore is kaolinite, although the occurrence of dickite in some mines located in Los Menucos area has been reported.

Marfil et al. (2005) studied kaolin deposits of the Blanquita and Equivocada mines from the Los Menucos area (Río Negro province). They are irregular bodies and veins developed on tuffs of rhyolitic composition. The mineralogy in the Blanquita mine is composed of dickite, kaolinite, alunite and pyrophyllite with a zonal distribution of these minerals. Alunite tends to be found in the core and kaolinite in the outer margins of the bodies. In the Equivocada mine, kaolinite is accompanied by dickite and small amounts of alunite (without pyrophyllite). The trace element 
content of kaolin samples is very similar in both deposits. $\delta^{18} \mathrm{O}$ of kaolinite ranges from $+4.8 \%$ o to $+10.3 \%$ and $\delta \mathrm{D}$ from -88 to $-116 \%$. These values are compatible with hydrothermal fluids of magmatic origin or with fluids of superficial origin isotopically equilibrated with the magmatic rocks at high temperatures. The values are far from those reported by Cravero \& Domínguez (1999) in deposits of residual origin from the Chubut and Santa Cruz provinces. The presence of pyrophyllite in the Blanquita mine indicates temperatures of formation of at least $350^{\circ} \mathrm{C}$.

The Loma Blanca mine is one of the northernmost kaolinized zones in the area of Los Menucos and is the only deposit hosted by andesitic rocks. The mineralization developed in two stages: the first stage, of higher temperature that pervasively affected the rock, led to the formation of dickite, pyrophyllite and diaspore. Then the temperature decreased due to mixing with meteoric water. Evidence of this second event is provided by the development of a new set of veins that intersect former faults whose mineral assemblage (kaolinite, natroalunite and iron oxides) is indicative of lower temperature conditions (Marfil et al., 2010).

Cravero et al. (2010) used a statistical method to discriminate between the kaolin deposits located in Patagonia, Argentina, formed by hypogene or supergene processes using chemical data. The supergene deposits of Patagonia are characterized by greater contents of $\mathrm{Fe}_{2} \mathrm{O}_{3}, \mathrm{Y}, \mathrm{Zr}, \mathrm{Rb}, \mathrm{U}$ and $R E E$. The REE have not undergone any fractionation during the weathering process. The hypogene deposits are characterized by greater contents of $\mathrm{Sr}$, $\mathrm{Pb}, \mathrm{V}, \mathrm{S}$ and $\mathrm{P}_{2} \mathrm{O}_{5}$, all of them, apart from $\mathrm{V}$, increasing as alteration proceeds. REE, probably forming part of the alunite structure, are fractionated during alteration. From all the elements that the statistical method discriminates as being more abundant in each type of deposit, the relationship $\mathrm{SO}_{3}$ vs. $\mathrm{P}_{2} \mathrm{O}_{5}$ as established by Dill et al. (1997, 2000) and REE behaviour seem to be the most representative.

The occurrence of hydrothermal events in the Los Menucos area is also proved by the presence of fluorite, baryte and $\mathrm{Pb}-\mathrm{Cu}-\mathrm{Zn}$ veins. Fluorite veins are hosted by rhyolites presenting an alteration mineralogy with sericite, carbonates, silica and kaolinite (Labudía \& Hayase, 1975). According to Manera (1972) and Hayase \& Manera (1973), homogenization temperatures of fluid inclusions in fluorite are between 150 and $240^{\circ} \mathrm{C}$. The presence of kaolinite and the formation temperatures of these veins suggest a possible relationship between fluorite-base metal veins and the studied kaolinite deposits of the area. In this case, kaolinite occurrences could be used as a prospecting tool for other types of mineral deposits in the region.

The aim of this study was to evaluate a kaolin deposit (Adelita mine) from Los Menucos area in the province of Río Negro, Argentina, identify the alteration minerals present and determine the relation between the chemical composition of major, minor and trace elements and the stable isotopes $(\mathrm{O}$ and $\mathrm{D})$ to confirm the genesis of the deposits and relate them to other deposits in the area.

These Patagonian deposits are derived from Mesozoic rhyolitic and andesitic rocks. There have been several studies aimed at discovering the origin of the primary deposits (Domínguez \& Murray, 1995, 1997; Cravero et al., 1991, 2001; Domínguez et al., 2008; Marfil et al., 2005). Most of the studies deal with the mineralogy, chemical composition, the deposit structure and oxygendeuterium isotope data.

\section{GEOLOGICAL SETTING AND SAMPLING}

Adelita is a kaolin mine located $8 \mathrm{~km} \mathrm{SW}$ of Los Menucos, province of Río Negro, Patagonia, Argentina, at approximately $850 \mathrm{~m}$ above sea level (Fig. 1). The mineralized zone, which has an approximate area of $100 \mathrm{~km}^{2}$ (5 to $8 \mathrm{~km}$ wide by $20 \mathrm{~km}$ long), hosts several kaolin deposits with similar characteristics. The material is hard, light brownish-grey and variable due to the high quartz and iron oxide content, stained and with strongly carbonated outcrop zones. The Adelita mine is located in the NE area of the mineralized zone and covers $5 \mathrm{~km}^{2}$ approximately (Fig. 2a). Three workings were developed; lower, middle and south, the last being located to the left of the others and at an intermediate level. In the lower working a profile was done on a $14 \mathrm{~m}$-high face; seven samples were taken and denominated 1-7 from the floor to the roof, respectively. The studied area is shown in Fig. $2 b$.

The middle working is about $15 \mathrm{~m}$ long. Five samples were collected and denominated 8-12 from the floor to the roof, respectively.

The third profile was done on the approximately $10 \mathrm{~m}$ high south working. Seven samples were 


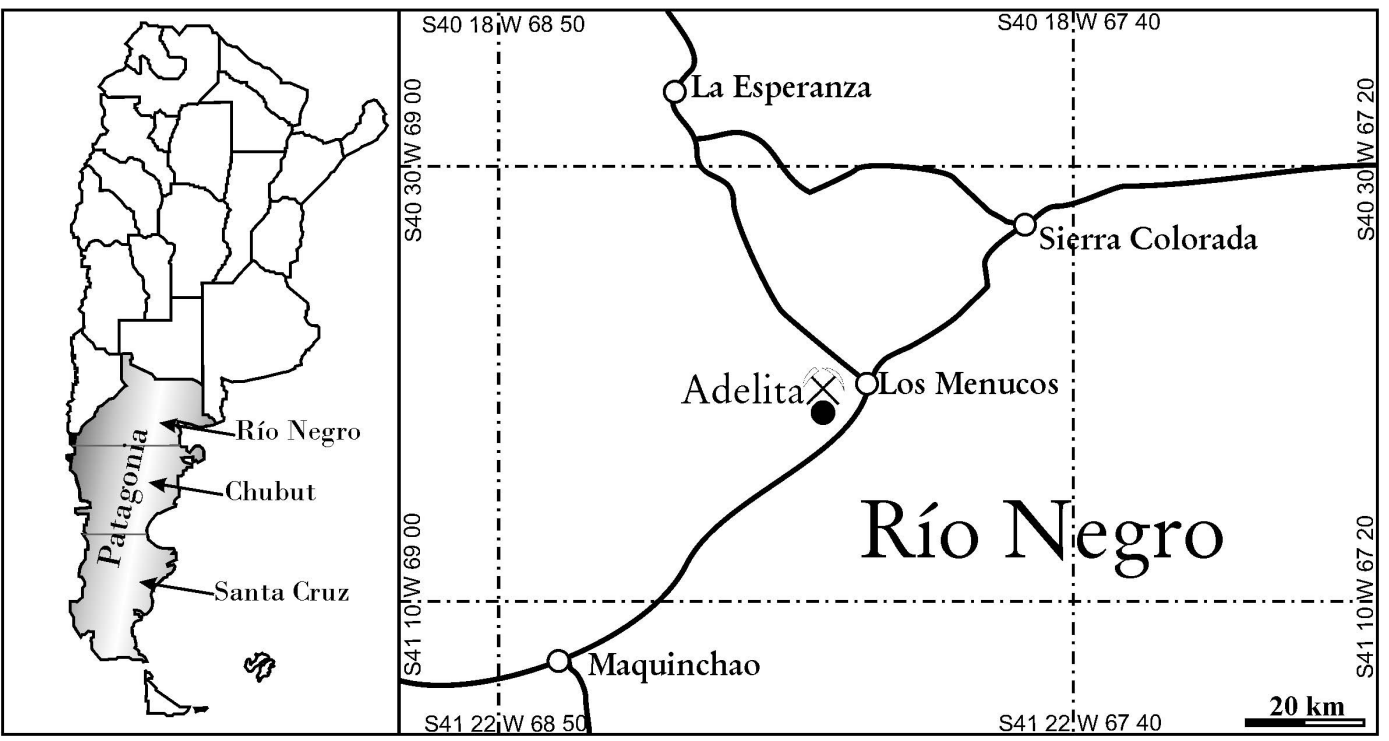

FIG. 1. Location of the Adelita mine.

collected and denominated $13-19$, from the floor to the roof, respectively.

The exposed kaolinized zone is $45 \mathrm{~m}$ thick and has been exposed by the mine workings. The floor has not been observed. The roof, with similar lithology, is strongly silicified. Although rocks do not crop out on the floor of the explored area, there is evidence of propylitization about $100 \mathrm{~m} \mathrm{SW}$, at a level approximately $10 \mathrm{~m}$ below the lower sample.

Kaolin deposits of the Los Menucos are enclosed in rhyolitic tuffs of the Sierra Colorada Formation, Upper Triassic to Middle Jurassic in age.

\section{ANALYTICAL METHODS}

A petrographic, textural, morphological and mineralogical study was carried out. An Olympus B2-UMA trinocular petrographic microscope with a built-in Sony $151 \mathrm{~A}$ video camera, a highresolution monitor and Image-Pro Plus image processing software were used. The mineralogical composition of bulk samples was determined by XRD, using a Rigaku D-Max III, with $\mathrm{Cu}-\mathrm{K \alpha}$ radiation and a graphite monochromator operated at $35 \mathrm{kV}$ and $15 \mathrm{~mA}$. The XRD patterns were

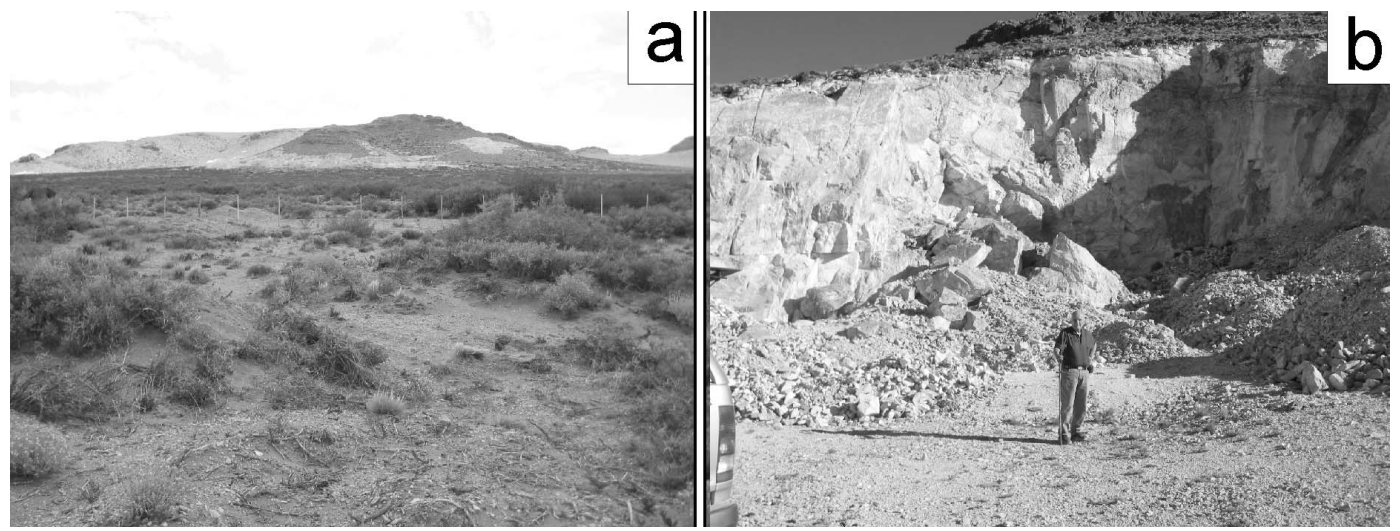

FIG. 2. (a) Adelita mine; (b) studied area. 
recorded from $2^{\circ}$ to $60^{\circ} 2 \theta$. Chemical analyses of bulk samples for major, minor and trace elements were carried out by inductively-coupled plasma mass-spectrometry (ICP). Kaolin samples were selected for $\mathrm{H}$ and $\mathrm{O}$ isotope, SEM, IR and DTATG analyses. Isotope results are presented as \% deviation with respect to SMOW. The reproducibility of results is better than $\pm 0.5 \%$ for $\mathrm{O}$ and $\pm 10 \%$ for $\mathrm{H}$.

\section{RESULTS}

\section{Petrography}

The mineralization at Adelita mine is enclosed in subhorizontal rhyolitic tuffs altered by epigenetic processes and has developed a weak lower alteration zone, mainly chloritized, which forms the floor of the deposit (Fig. 3a).

These rhyolitic tuffs show irregular cracks, have flow texture and zones with microgranular matrix. Biotite and quartz phenocrysts up to $3 \mathrm{~mm}$ long, sanidine and oligoclase are abundant. Feldspars and mafic minerals are altered, mainly chloritized, kaolinized and carbonated and usually cracked. In some zones the matrix contains abundant volcanic glass and sometimes has perlitic texture. The rock is composed of abundant lithic particles of variable size $(0.01-2 \mathrm{~mm})$ although they may be $5 \mathrm{~cm}$ or greater, forming agglomerate levels. It is usually strongly altered, mainly kaolinized and silicified. This latter process, which develops at the upper levels of the deposits, has protected them against erosion, creating a soft undulating landscape.

The kaolinized zone is $45 \mathrm{~m}$ thick, with irregular lithological variation, where ignimbritic levels interlayered with quartz lithic tuffs occur. The roof consists of fine-grained rhyolitic tuffs, highly silicified, stained with iron oxides that are highly resistant to subsequent erosion processes.

The zone with the highest degree of kaolinization developed where the texture was coarser, more permeable and with a greater content of volcanic glass in the matrix. Some glassy lenses preserve their slightly fluidal texture, whereas those that have been slightly altered reveal the original pisolitic textures (Fig. 3b). Other glassy lenses are completely kaolinized, and in the ones occurring at the deepest levels the characteristic mineralization is dickite with isolated diaspore crystals (Fig. 3c). Small alunite crystals dispersed in the kaolinized matrix were also identified.
Kaolinization occurs mainly in the reactive zones of the host rock, i.e. the matrix, fiammes (glass lenses) or in sites that are more permeable owing to a favourable texture due to lithology or structure. Although they are not common, levels where the tuff has been brecciated have been identified, especially in the upper levels (Fig. 3d). Relics of rhyolitic tuff have been identified; the original texture is preserved and the only primary mineral is quartz (Fig. 3e).

Kaolin occurs as massive replacement of phenocrysts and the matrix obliterating the original texture of the rock, and is also present in veins. The only primary mineral that is preserved is fractured quartz with signs of corrosion (Fig. 3f).

Fine-grained secondary quartz is abundant; it replaces the primary minerals and is distributed in the matrix and as veins. Mafic minerals only preserve their morphology due to the mobilization of iron towards the outer zones and in the cleavage of the primary mineral.

Kaolinization is stronger at deep levels. It is characterized by a dickite-quartz assemblage with relics of diaspore and alunite concentrated at the ignimbritic levels, especially at those with a higher percentage of glass.

Mineralization has reached moderate levels except for the veins, where the ore does not exceed $25 \% \quad \mathrm{Al}_{2} \mathrm{O}_{3}$; it is light brownish-grey, stained with iron, manganese and titanium oxides and it contains variable amounts of original lithic material as impurities.

One of the roof samples showed evidence of a strong carbonation process caused by the percolation of circulating water related to the exogenous environment.

\section{Chemical composition}

The results of the chemical analyses of major, minor and trace elements of the samples taken from the Adelita mine are listed in Table 1. The silica content increases from the base to the roof in the three profiles of each of the workings middle, lower and south. Sample 15, which corresponds to a vein at the base of the south working, is the zone with the greatest degree of kaolinization. The $\mathrm{SiO}_{2}, \mathrm{Al}_{2} \mathrm{O}_{3}$ and $\mathrm{H}_{2} \mathrm{O}$ values found for this sample are similar to the theoretical values calculated for a pure kaolin sample. The alumina content is constant in almost all the samples from the three profiles. 


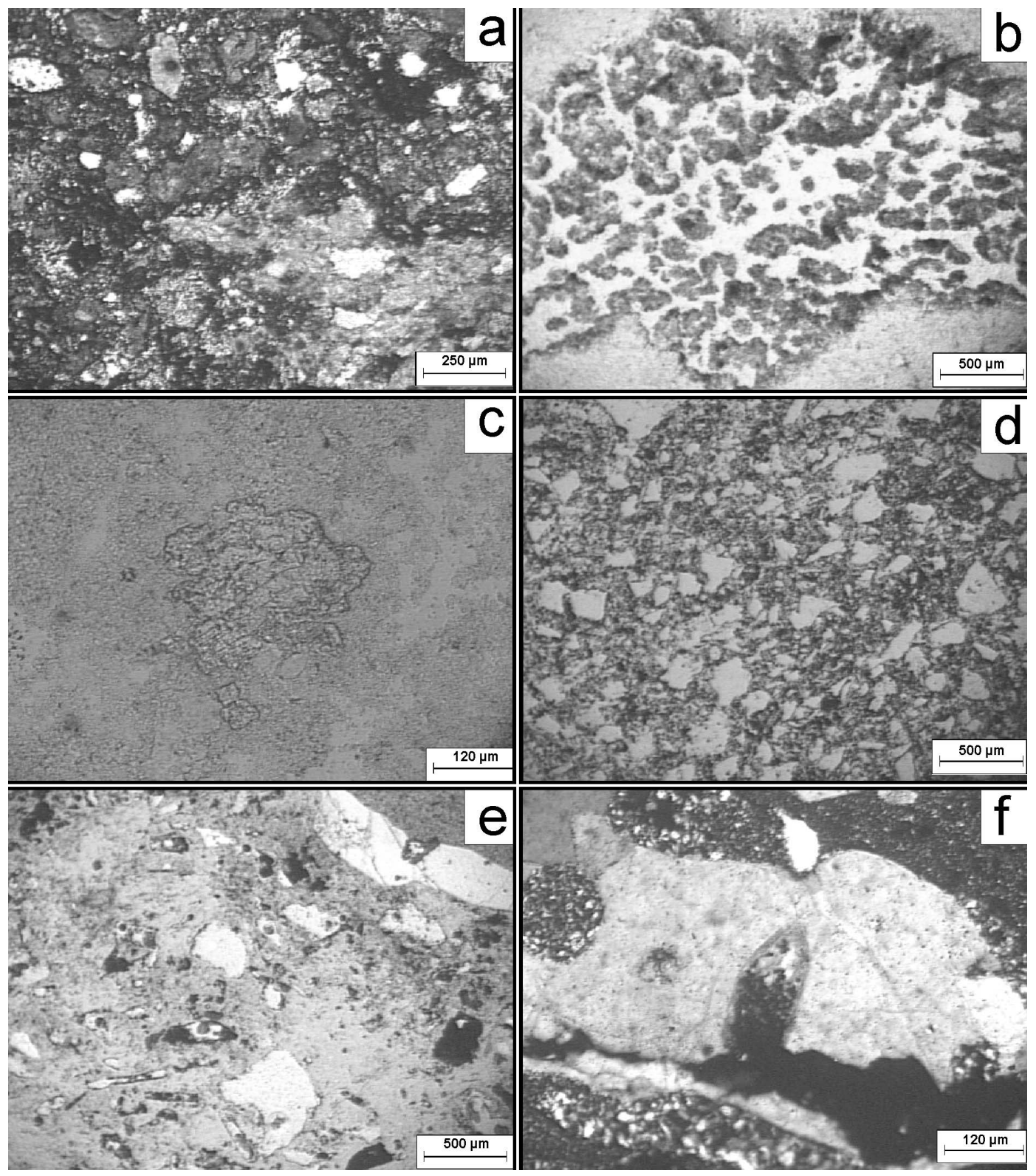

FIG. 3. (a) Chloritized rhyolitic tuffs from the floor of the deposit. (b) Glassy lenses with slightly fluidal texture and pisolitic textures. (c) Isolated diaspore crystal. (d) Brecciated tuff from the upper levels. (e) Relicts of rhyolitic tuff. (f) Fractured quartz with signs of corrosion.

Figure 4 shows the most representative variation diagrams, especially those of the elements that vary with the degree of alteration, indicating that they are concentrated mainly in the argillaceous minerals. There is a good correlation between
$\mathrm{Al}_{2} \mathrm{O}_{3}$ and LOI, with sample 15 having the greatest alumina content, which coincides with the greatest kaolin content.

$\mathrm{P}_{2} \mathrm{O}_{5}$ shows a good correlation with LOI. Its content increases with the degree of alteration as in 
TABLE 1. Chemical analysis of major (wt.\%) and trace elements (ppm) in samples from the Adelita mine.

\begin{tabular}{|c|c|c|c|c|c|c|c|c|c|c|}
\hline \multirow[t]{2}{*}{ Sample } & \multicolumn{3}{|c|}{ - Middle working - } & \multicolumn{2}{|c|}{ Lower working } & \multirow[b]{2}{*}{20} & \multirow{2}{*}{$\frac{}{14} \mathrm{~S}$} & \multirow{2}{*}{$\begin{array}{c}\text { South working } \\
17\end{array}$} & \multirow[b]{2}{*}{15} & \multirow[b]{2}{*}{16} \\
\hline & 1 & 5 & 6 & 10 & 12 & & & & & \\
\hline $\mathrm{SiO}_{2}$ & 76.07 & 76.51 & 71.52 & 80.5 & 66.3 & 77.27 & 78.52 & 47.42 & 84.43 & 79.29 \\
\hline $\mathrm{TiO}_{2}$ & 0.23 & 0.14 & 0.14 & 0.13 & 0.16 & 0.23 & 0.25 & 0.01 & 0.17 & 0.16 \\
\hline $\mathrm{Al}_{2} \mathrm{O}_{3}$ & 15.74 & 16.56 & 18.62 & 14.4 & 24.42 & 16.59 & 14.01 & 37.71 & 11.74 & 13.57 \\
\hline $\mathrm{Fe}_{2} \mathrm{O}_{3} \mathrm{~T}$ & 0.16 & 0.09 & 0.24 & 0.09 & 0.12 & 0.16 & 0.11 & 0.09 & 0.15 & 0.07 \\
\hline $\mathrm{MnO}$ & 0.001 & 0.002 & 0.001 & 0.001 & 0.001 & 0.002 & 0.001 & 0.001 & 0.001 & 0.001 \\
\hline $\mathrm{MgO}$ & 0.07 & 0.08 & 0.23 & 0.02 & 0.05 & 0.01 & 0.02 & 0.6 & 0.05 & 0.04 \\
\hline $\mathrm{CaO}$ & 0.23 & 0.41 & 0.10 & 0.03 & 0.03 & 0.04 & 0.04 & 0.15 & 0.005 & 0.03 \\
\hline $\mathrm{Na}_{2} \mathrm{O}$ & 0.27 & 0.03 & 0.04 & 0.02 & 0.03 & 0.04 & 0.03 & 0.03 & 0.03 & 0.02 \\
\hline $\mathrm{K}_{2} \mathrm{O}$ & 0.05 & 0.05 & 0.07 & 0.04 & 0.03 & 0.04 & 0.04 & 0.01 & 0.03 & 0.03 \\
\hline $\mathrm{P}_{2} \mathrm{O}_{5}$ & 0.14 & 0.11 & 0.16 & 0.06 & 0.14 & 0.07 & 0.06 & 0.01 & 0.01 & 0.07 \\
\hline LOI & 6.77 & 6.65 & 7.58 & 5.24 & 8.66 & 6.03 & 5.35 & 13.87 & 4.28 & 5.12 \\
\hline Total & 99.74 & 100.6 & 98.7 & 100.5 & 99.94 & 100.5 & 98.44 & 99.9 & 100.9 & 98.4 \\
\hline $\mathrm{Ba}$ & 511 & 318 & 301 & 574 & 147 & 606 & 850 & 2754 & 5733 & 598 \\
\hline $\mathrm{Rb}$ & 2 & 3 & 3 & 2 & 1 & 1 & 4 & 1 & 2 & 3 \\
\hline $\mathrm{Sr}$ & 1186 & 864 & 1501 & 654 & 1407 & 683 & 661 & 46 & 195 & 757 \\
\hline Y & 5.4 & 5.4 & 5 & 5.1 & 7.9 & 4.9 & 5.6 & 0.6 & 5.6 & 5.7 \\
\hline $\mathrm{Zr}$ & 116 & 106 & 95 & 96 & 113 & 124 & 114 & 23 & 108 & 114 \\
\hline $\mathrm{Nb}$ & 11.2 & 10.6 & 11.1 & 11.2 & 11.4 & 11.9 & 10.8 & 0.6 & 11.2 & 12.2 \\
\hline $\mathrm{Th}$ & 13.2 & 14.1 & 13.4 & 11.3 & 14.3 & 14.4 & 11.9 & 0.43 & 7.86 & 13.1 \\
\hline $\mathrm{Pb}$ & 37 & 27 & 39 & 25 & 21 & 32 & 87 & 9 & 21 & 56 \\
\hline $\mathrm{Ga}$ & 23 & 23 & 23 & 15 & 26 & 21 & 33 & 67 & 23 & 26 \\
\hline $\mathrm{Zn}$ & 30 & 30 & 30 & 30 & 30 & 30 & 30 & 30 & 30 & 30 \\
\hline $\mathrm{Cu}$ & 10 & 10 & 10 & 10 & 10 & 10 & 10 & 10 & 10 & 10 \\
\hline $\mathrm{Ni}$ & 20 & 20 & 20 & 20 & 20 & 20 & 20 & 20 & 20 & 20 \\
\hline V & 57 & 34 & 67 & 35 & 54 & 44 & 17 & 27 & 17 & 22 \\
\hline $\mathrm{Cr}$ & 20 & 20 & 20 & 20 & 20 & 20 & 20 & 20 & 20 & 20 \\
\hline $\mathrm{Hf}$ & 3.3 & 2.9 & 2.8 & 2.7 & 3 & 3.2 & 3.1 & 0.7 & 3.2 & 3.1 \\
\hline Cs & 0.6 & 0.9 & 0.6 & 0.5 & 0.3 & 0.8 & 0.7 & 0.1 & 0.4 & 0.4 \\
\hline $\mathrm{Sc}$ & 5 & 5 & 5 & 5 & 6 & 6 & 4 & 2 & 3 & 4 \\
\hline $\mathrm{Ta}$ & 1.24 & 1.24 & 1.17 & 1.18 & 1.25 & 1.26 & 1.27 & 0.07 & 1.39 & 1.46 \\
\hline Co & 1 & 1 & 1 & 1 & 1 & 1 & 1 & 1 & 1 & 1 \\
\hline $\mathrm{Be}$ & 1 & 1 & 1 & 1 & 1 & 1 & 1 & 1 & 1 & 1 \\
\hline U & 3.12 & 3.57 & 3.01 & 4.27 & 5.21 & 3.32 & 3.08 & 0.24 & 2.65 & 3.18 \\
\hline W & 6.1 & 0.5 & 3.1 & 2.3 & 0.6 & 2.8 & 2 & 0.5 & 1.5 & 1.8 \\
\hline $\mathrm{Sn}$ & 2 & 2 & 2 & 2 & 2 & 2 & 2 & 2 & 2 & 2 \\
\hline Mo & 2 & 0 & 2 & 2 & 2 & 3 & 2 & 2 & 2 & 2 \\
\hline $\mathrm{La}$ & 32.5 & 31.9 & 33.6 & 28.2 & 29.9 & 33.7 & 24 & 0.63 & 10.8 & 30.3 \\
\hline $\mathrm{Ce}$ & 52.6 & 54.9 & 55.9 & 44.1 & 44.3 & 54.7 & 39.3 & 1.04 & 17.6 & 49.8 \\
\hline $\operatorname{Pr}$ & 4.58 & 4.76 & 4.97 & 3.56 & 3.62 & 4.78 & 3.48 & 0.09 & 1.46 & 4.26 \\
\hline $\mathrm{Nd}$ & 13.1 & 14.4 & 14.4 & 10.1 & 10.5 & 14.4 & 10.6 & 0.47 & 4.11 & 13 \\
\hline $\mathrm{Sm}$ & 1.82 & 1.95 & 1.81 & 1.37 & 2.04 & 1.97 & 1.57 & 0.14 & 0.55 & 1.43 \\
\hline $\mathrm{Eu}$ & 0.261 & 0.238 & 0.298 & 0.2 & 0.332 & 0.294 & 0.205 & 0.005 & 0.005 & 0.255 \\
\hline $\mathrm{Gd}$ & 0.92 & 0.93 & 1.05 & 0.88 & 1.28 & 0.97 & 1.07 & 0.19 & 0.77 & 0.94 \\
\hline $\mathrm{Tb}$ & 0.13 & 0.14 & 0.16 & 0.14 & 0.18 & 0.14 & 0.16 & 0.03 & 0.14 & 0.15 \\
\hline Dy & 0.72 & 0.82 & 0.84 & 0.83 & 1.09 & 0.78 & 0.94 & 0.12 & 0.89 & 0.91 \\
\hline Но & 0.17 & 0.17 & 0.18 & 0.17 & 0.24 & 0.17 & 0.21 & 0.03 & 0.2 & 0.2 \\
\hline $\mathrm{Er}$ & 0.59 & 0.54 & 0.58 & 0.52 & 0.77 & 0.56 & 0.66 & 0.08 & 0.63 & 0.6 \\
\hline Tm & 0.104 & 0.085 & 0.095 & 0.09 & 0.122 & 0.101 & 0.114 & 0.016 & 0.098 & 0.102 \\
\hline $\mathrm{Yb}$ & 0.78 & 0.58 & 0.71 & 0.7 & 0.85 & 0.72 & 0.82 & 0.12 & 0.74 & 0.77 \\
\hline $\mathrm{Lu}$ & 0.136 & 0.096 & 0.117 & 0.121 & 0.139 & 0.122 & 0.139 & 0.021 & 0.129 & 0.133 \\
\hline
\end{tabular}



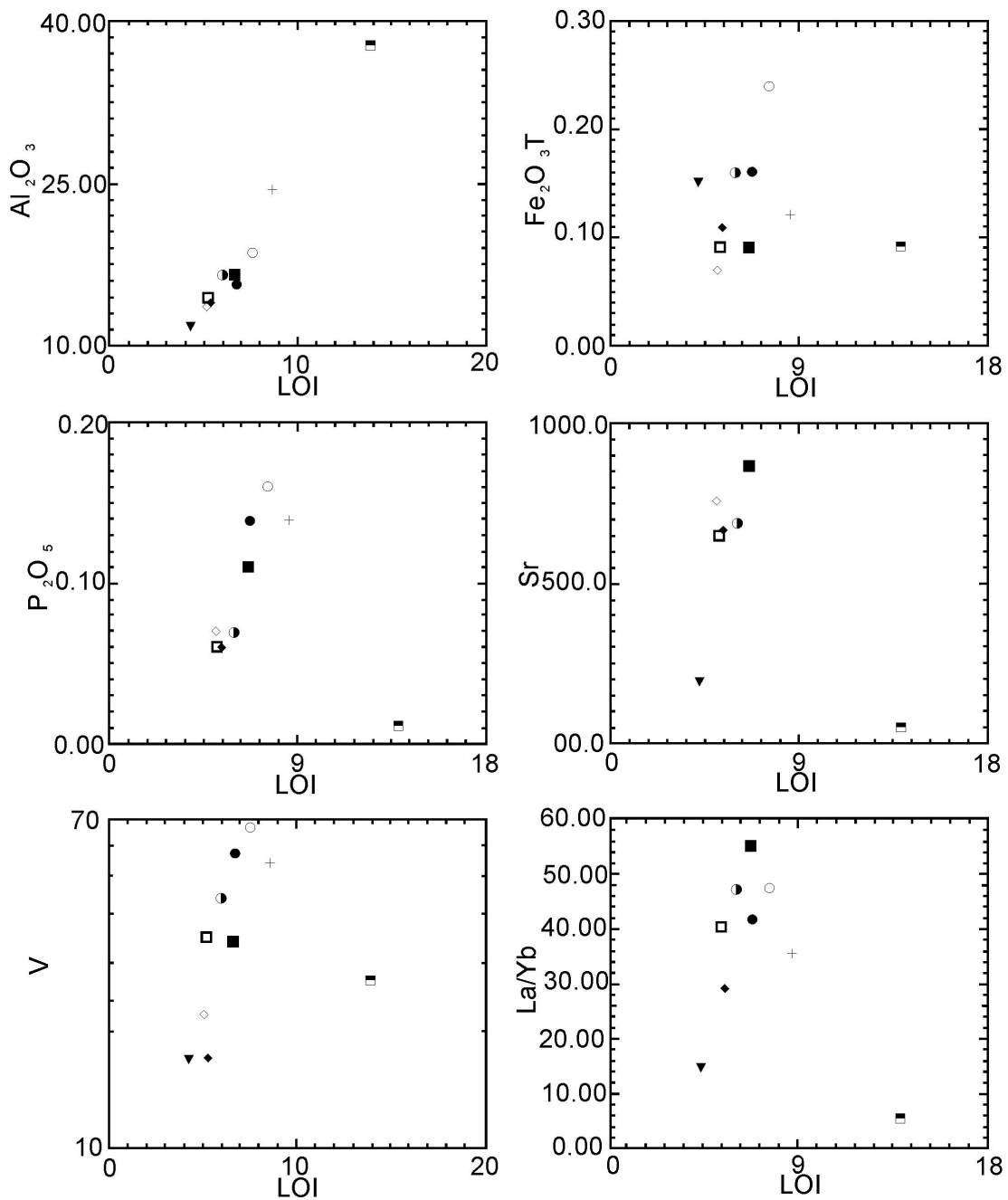

FIG. 4. Data plot of samples from Adelita mine. LOI vs. $\mathrm{Al}_{2} \mathrm{O}_{3}, \mathrm{Fe}_{2} \mathrm{O}_{3}, \mathrm{P}_{2} \mathrm{O}_{5}, \mathrm{Sr}, \mathrm{V}$ and $\mathrm{La}_{\mathrm{N}} / \mathrm{Yb}_{\mathrm{N}}$. References symbols:

: $12,+: 2$ 14, $8, \bigcirc: 9$,

$\square: 10, \nabla: 16, \diamond: 17, \mathbf{J}: 13$, 15.

samples 2, 8, 9, 13 and 14, which are from deeper zones of the profile.

The greatest $\mathrm{CaO}$ content is that of sample 12, which was collected from the upper part of the middle working of the quarry where strong carbonation is observed. Alkali concentrations are very low as in the case of $\mathrm{MnO}$ and $\mathrm{MgO}$, and decrease with the increase in kaolin, which ranges between $31 \%$ and $65 \%$. The $\mathrm{Fe}_{2} \mathrm{O}_{3}$ content is low for all the samples analysed.

$\mathrm{Sr}, \mathrm{V}$ and $\mathrm{Pb}$ concentrations are relatively high. $\mathrm{Zr}, \mathrm{Co}, \mathrm{Ni}, \mathrm{Cu}, \mathrm{Zn}$ and $\mathrm{Rb}$ show no variation with the degree of alteration and occur in very low concentrations. The relationship $\mathrm{La}_{\mathrm{N}} / \mathrm{Yb}_{\mathrm{N}} v$ s. LOI shows a positive trend that is directly related to the progress in the degree of alteration; these variations are characteristic of hypogene environments.

\section{Mineralogy}

Samples of pure kaolin were collected from the vein zones to be studied by polarization microscopy on thin sections, SEM, DTA-TG, IR and $\delta^{18} \mathrm{O}$ and $\delta \mathrm{D}$ isotope analyses. 

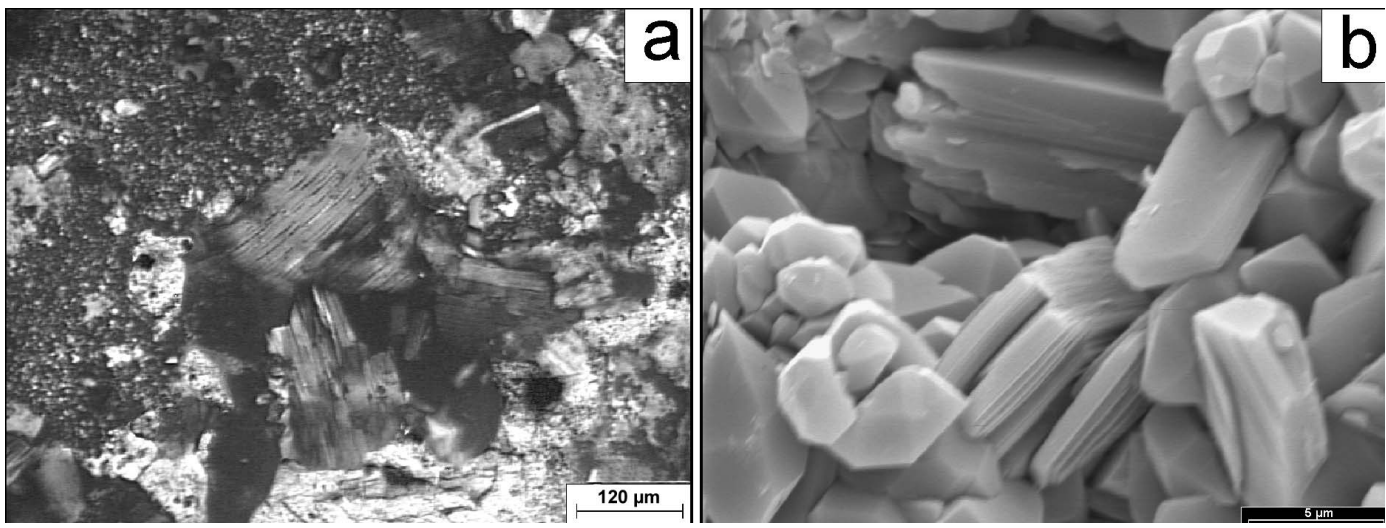

FIG. 5. (a) Dickite crystals in thin section. (b) SEM: large dickite packages contained in a well crystallized kaolinite mass.

\section{Polarization microscopy}

Dickite crystals are a few microns in size and can be above $200 \mu \mathrm{m}$ in the vein zones (Fig. 5a). It is a lamellar, fibrous mineral, with a refractive index of $1.560-1.566$ with very low birefringence -0.006 . It has positive elongation. The extinction is almost parallel with an extinction angle below $5^{\circ}$.

\section{Scanning electron microscopy}

SEM observations allow the identification of large dickite packages contained in a well crystallized kaolinite mass. Kaolin morphology is shown in Fig. 5 b.

\section{$X$-ray diffraction}

The samples collected from the floor to the roof of the quarry are composed of kaolin, with variable amounts of quartz. A detailed analysis of the triplets located between $34^{\circ}$ and $40^{\circ}(2 \theta)$ showed that dickite prevails over kaolinite. Figure 6 shows an XRD pattern in this range where the reflections of both minerals can be identified.

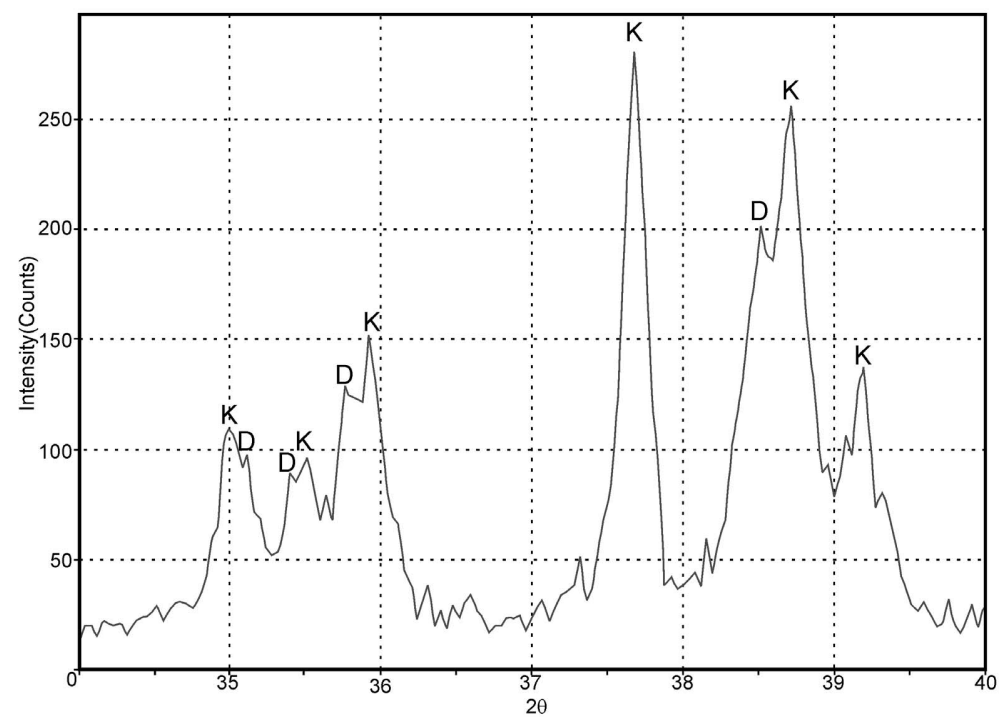

FIG. 6. XRD: detail of the triplets located between $34^{\circ}$ and $40^{\circ} 2 \theta$ where dickite (D) and kaolinite (K) were identified. 


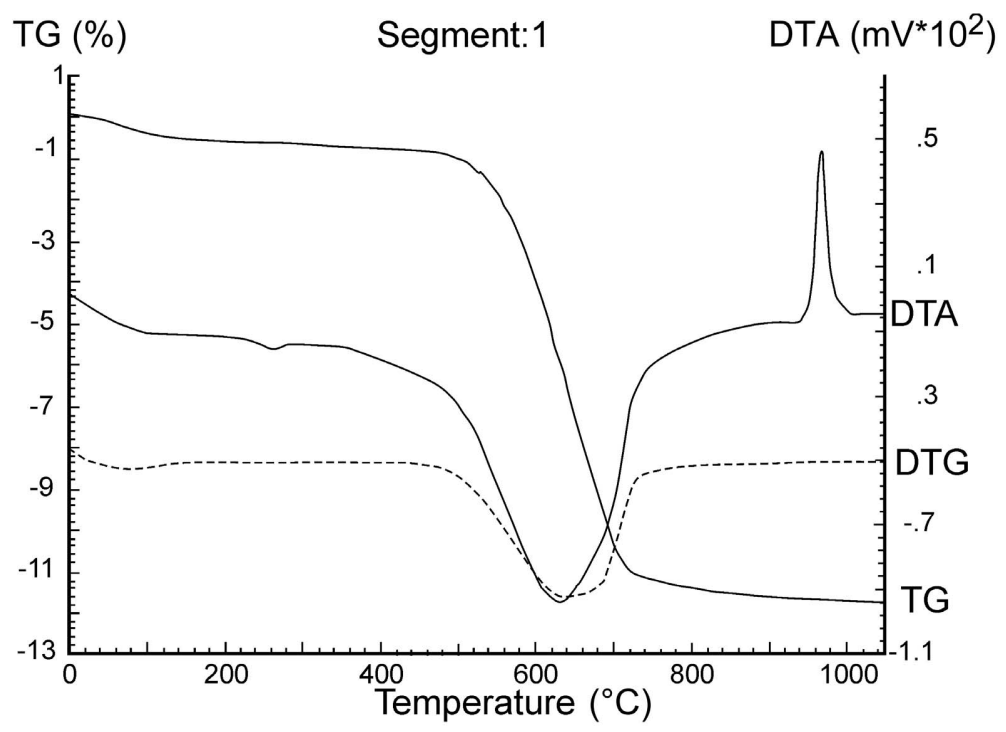

FIG. 7. Differential thermal analysis-thermal gravimetry (DTA-TG) pattern of dickite + kaolinite.

\section{$D T A-T G$}

Figure 7 shows an endothermic peak at $638^{\circ} \mathrm{C}$, which corresponds to dickite. The exothermic peak appears at $990^{\circ} \mathrm{C}$ (Mackenzie, 1970). The LOI of the sample analysed is $11.1 \%$. Taking into account that the theoretical water content of kaolinite is $13.9 \%, 80 \%$ purity is assumed. The rest is quartz.

\section{Infrared spectra}

Figure 8 shows the IR diagrams with absorption bands at $3.698 \mathrm{~cm}^{-1}, 3.658 \mathrm{~cm}^{-1}$ and $3.620 \mathrm{~cm}^{-1}$, corresponding to the $\mathrm{O}-\mathrm{H}$ link; between 400 and $600 \mathrm{~cm}^{-1}$, to the Al-O link, and between 1000 and $1100 \mathrm{~cm}^{-1}$, to the Si-O link, which are characteristic of dickite (van del Marel \& Beutelspacher, 1976).

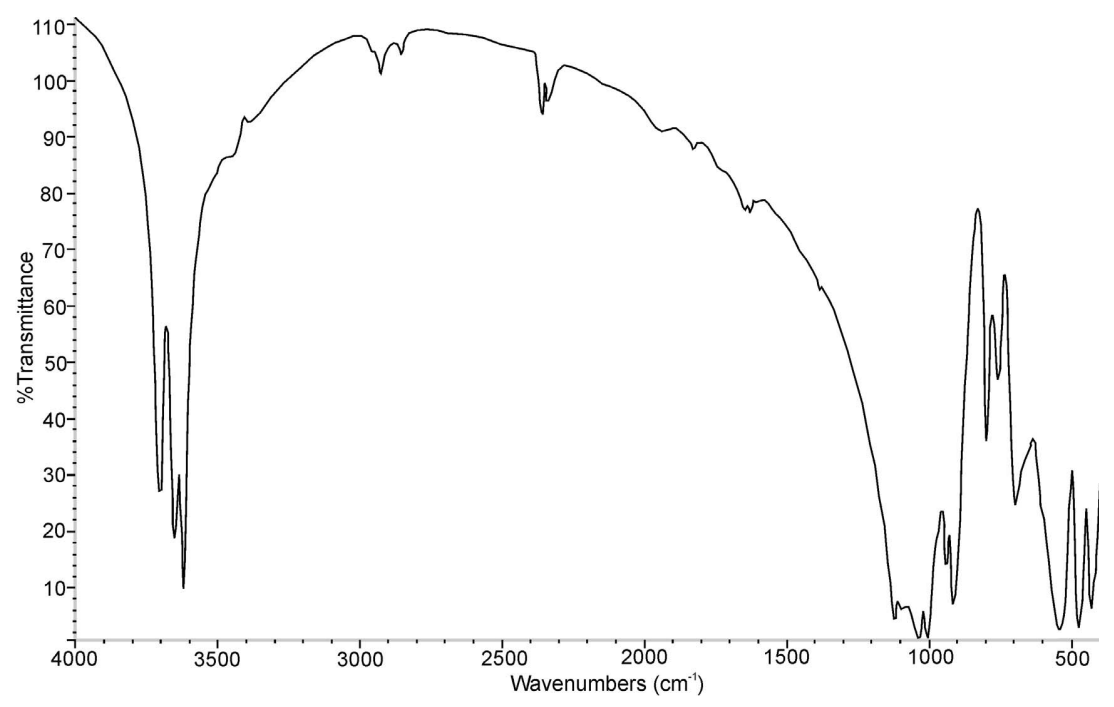

FIG. 8. Infrared pattern of dickite. 


\section{$O$ and $H$ isotopes}

Representative samples were taken from the vein zones to perform isotope studies. The $\delta^{18} \mathrm{O}$ and $\delta \mathrm{D}$ values range from $3.8 \%$ to $7.7 \%$ and from $-123 \%$ to $-103 \%$, respectively. In Fig. 9 the values obtained are compared with those reported by Marfil et al. (2005) and Maiza et al. (2009) for kaolin deposits of hydrothermal origin, and with those reported by Cravero et al. $(1991,2001)$ for kaolins of residual and sedimentary environments.

\section{DISCUSSION}

Dill et al. $(1997,2000)$ used the relationships $\left(\mathrm{TiO}_{2}\right.$ $+\mathrm{Fe}_{2} \mathrm{O}_{3}$ v vs. $(\mathrm{Cr}+\mathrm{Nb}), \mathrm{Zr} v s$. $\mathrm{TiO}_{2}$, and $(\mathrm{Ba}+\mathrm{Sr})$ vs. $(\mathrm{Ce}+\mathrm{Y}+\mathrm{La})$ to discriminate between hypogene and supergene kaolinization processes. They found that $\mathrm{S}, \mathrm{Ba}$ and $\mathrm{Sr}$ are enriched during hydrothermal alteration, whereas $\mathrm{Cr}, \mathrm{Nb}, \mathrm{Ti}$ and lanthanide elements are concentrated mainly during weathering. The diagrams (Fig. 10) show that the samples from the Adelita mine plot in the hypogene field. The $(\mathrm{Ba}+\mathrm{Sr})$ concentrations vary between 600 and $6000 \mathrm{ppm}$ and $(\mathrm{Ce}+\mathrm{Y}+\mathrm{La})$ between 2 and $150 \mathrm{ppm}$; $(\mathrm{Cr}+\mathrm{Nb})$ remains constant for all the samples (between 20 and $31 \mathrm{ppm}$ ), whereas $\left(\mathrm{TiO}_{2}+\mathrm{Fe}_{2} \mathrm{O}_{3}\right.$ ) is below $0.3 \%$. In the hypogene deposits $\mathrm{P}_{2} \mathrm{O}_{5}$ is also more abundant and increases with the degree of alteration. These values differ from those reported by Cravero et al. (2001) for kaolins of supergene origin located in the provinces of Santa Cruz and Chubut. The latter have greater $\mathrm{Ti}+\mathrm{Fe}$ and Ce contents.

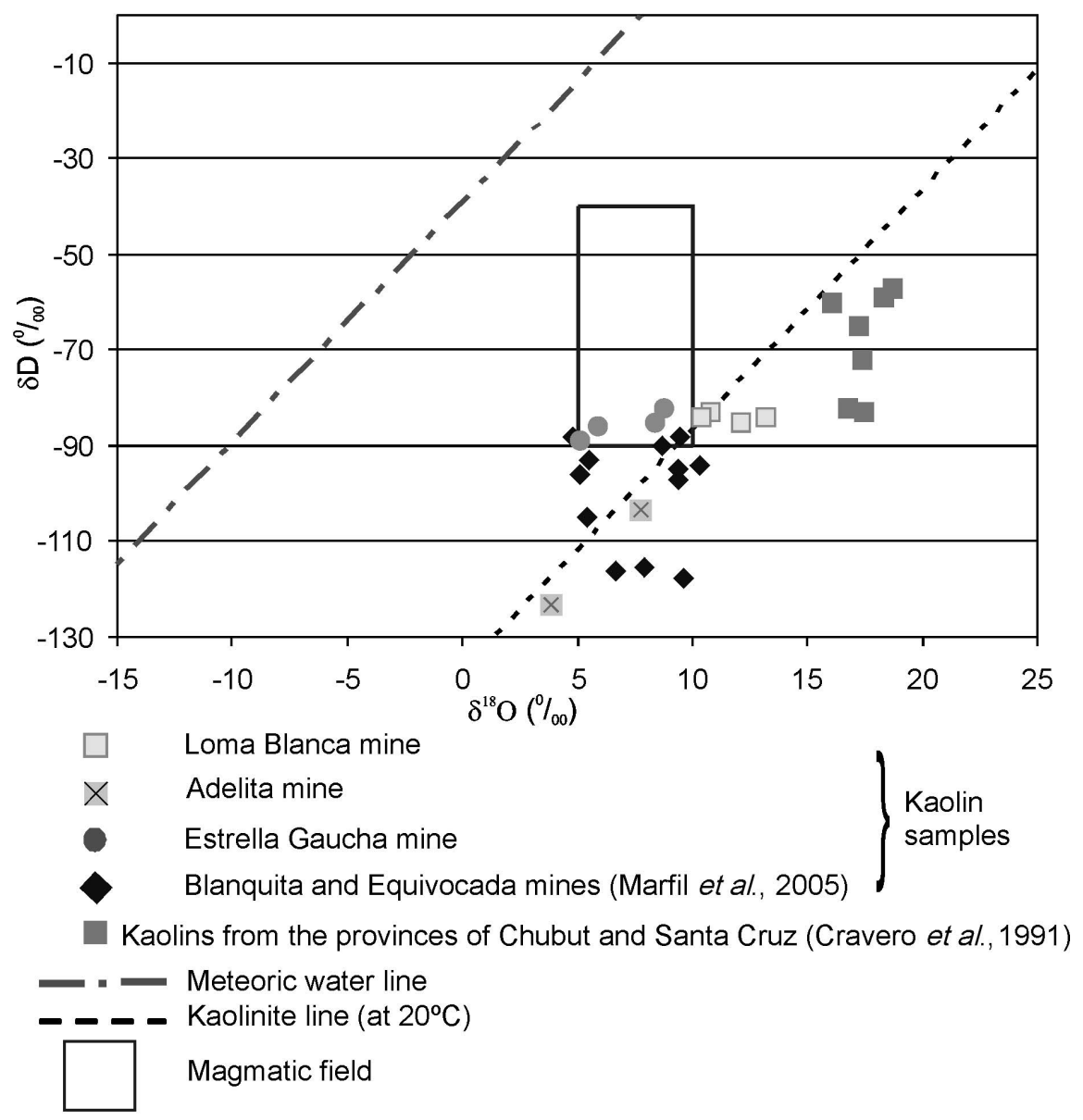

FIG. 9. $\delta^{18} \mathrm{O}$ and $\delta \mathrm{D}$ values in Adelita are compared with those from Loma Blanca, Estrella Gaucha, Blanquita, Equivocada mines. Also data plot of samples from Santa Cruz kaolin deposits (Cravero et al., 2001). 

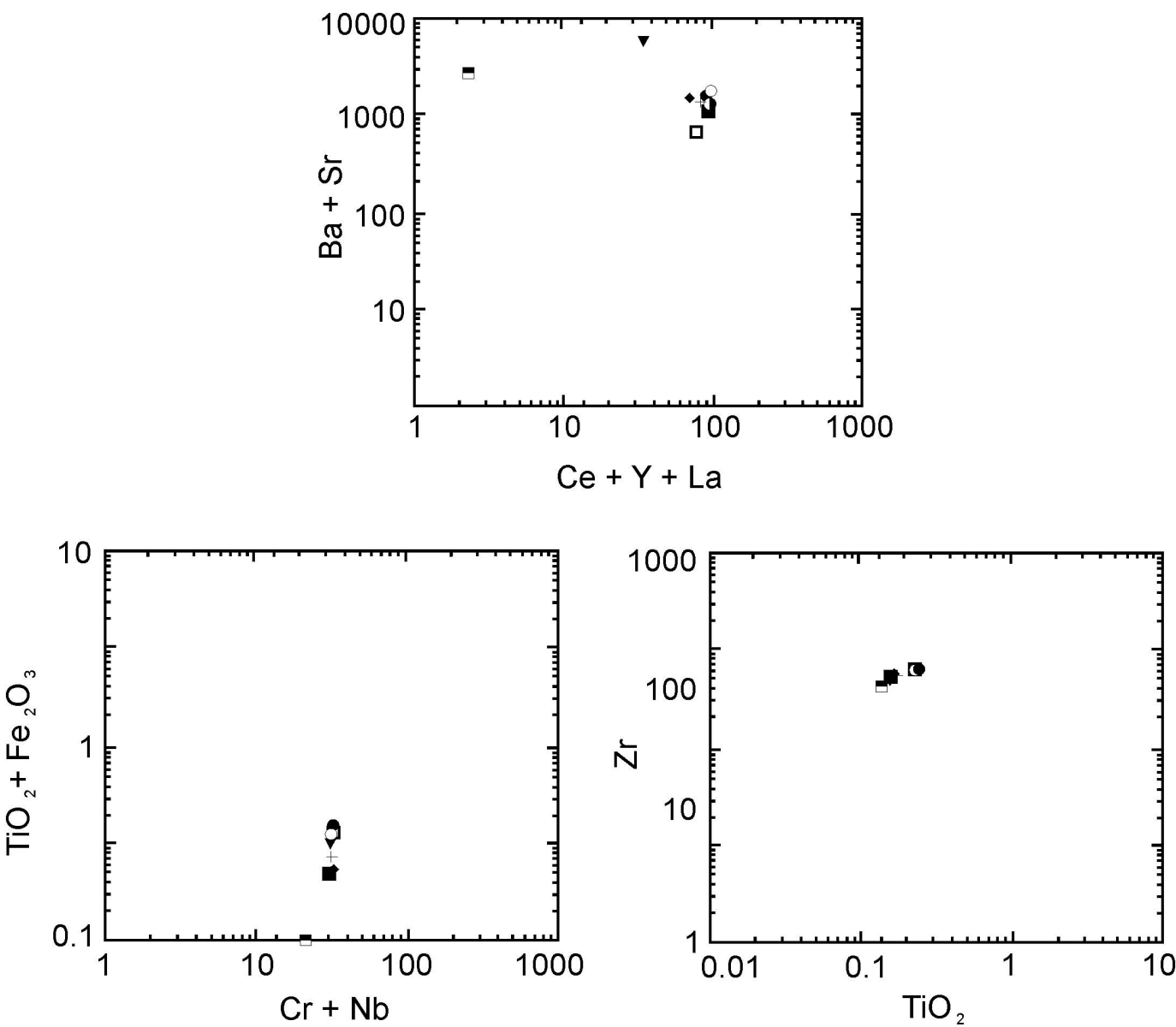

Fig. 10. Data plot of kaolin samples from Adelita mine: $\left(\mathrm{TiO}_{2}+\mathrm{Fe}_{2} \mathrm{O}_{3}\right) v s .(\mathrm{Cr}+\mathrm{Nb}), \mathrm{Zr} v s . \mathrm{TiO}_{2}$ and $(\mathrm{Ba}+\mathrm{Sr}) v s$. $(\mathrm{Ce}+\mathrm{Y}+\mathrm{La})$.

Titanium may be released from a primary mineral in the parent rock (e.g. biotite) during either hypogene or supergene kaolinization. However, as supergene alteration seems to be more efficient, the $\mathrm{Ti}$ content in kaolinite has been used to discriminate between the two processes (Dill et al., 1997). Because it behaves as a geochemically immobile element in superficial conditions, $\mathrm{Zr}$ is also a good indicator of the degree of meteorization of the parent rock. Consequently, kaolin samples with high $\mathrm{Ti}$ and $\mathrm{Zr}$ contents point to a superficial environment of formation (Marfil et al. 2005).

Cravero et al. (2010) compared kaolin deposits of hypogene and supergene origin from Patagonia, Argentina. In the hypogene deposits, $\mathrm{S}, \mathrm{Sr}, \mathrm{Pb}, \mathrm{V}$,
$\mathrm{P}_{2} \mathrm{O}_{5}$ and $L R E E$ are more abundant, whereas $\mathrm{Fe}_{2} \mathrm{O}_{3}$, $\mathrm{Y}, \mathrm{Rb}, \mathrm{U}, \mathrm{Zr}$ and HREE predominate in the supergene (weathered) deposits. It is important to consider that the samples are altered and the degree of alteration is not the same in all of them. The main alteration products in all the samples are clay minerals of the kaolin group. The approach adopted is to consider that the greater the LOI is, the greater the resulting alteration degree results. The concentrations of $\mathrm{S}, \mathrm{Pb}$ and $\mathrm{Sr}$, present only in the hypogene deposits, vary with the degree of alteration, indicating that these elements are mainly concentrated in the clay minerals. $\mathrm{Zr}$ does not show a clear behaviour; in the hypogene deposits it appears to be mobile during alteration, whereas under weathering conditions no clear relationship 
can be established. The $\mathrm{V}$ and $\mathrm{U}$ contents increase in both types of deposits with the degree of alteration; hence they can be considered to be immobile in both environments. $\mathrm{P}_{2} \mathrm{O}_{5}$ and $\mathrm{S}$ are only present in hypogene deposits and their contents increase with the alteration degree.

Chondrite-normalized rare earth element diagrams according to Boynton (1984) (Fig. 11) are characterized by a marked enrichment in LREE relative to $H R E E$ and negative europium anomalies. There is almost no variation in HREE content. The samples from the vein zone show REE impoverishment and a very marked europium negative anomaly. A clear parallelism with respect to the rest of the samples is observed. There are no positive $\mathrm{Ce}$ anomalies, which are characteristic of residual or meteoric deposits (Cravero et al., 2001). The relationship $\mathrm{La}_{\mathrm{N}} / \mathrm{Yb}_{\mathrm{N}}$ vs. LOI increases as the degree of alteration typical of hypogene environments increases.

The samples from Patagonia studied by Cravero et al. (2010) have been taken as representative of the whole altered area, so the element contents do not come from a specific part of the weathering profile; therefore it can be considered that the conservative behaviour of the REE arises from the fact that fractionation could have occurred within the profile. A characteristic of the REE that supports a supergene origin is the presence of a $\mathrm{Ce}$ anomaly, produced when $\mathrm{Ce}^{3+}$ is oxidized to $\mathrm{Ce}^{4+}$. When these data are plotted in the graphical style of Dill et al. (1997, 2000), some of the relationships are not as clear as in their work, except for $\mathrm{SO}_{3}$ vs. $\mathrm{P}_{2} \mathrm{O}_{5}$. Their supergene deposits are characterized by much greater contents of $\mathrm{Ce}+$ $\mathrm{Y}+\mathrm{La}$ than those formed under hypogene conditions, whereas in Patagonia these values are dispersed. In Peru, supergene kaolins are characterized by large values of both $\mathrm{TiO}_{2}$ and $\mathrm{Zr}$, whereas in Patagonia only $\mathrm{Zr}$ shows the same behaviour. $\mathrm{Cr}$ $+\mathrm{Nb}$ also show the opposite trend, while in Peru the greatest contents are related to a supergene origin; in Patagonia they are associated with hydrothermal deposits. In both areas, the same behaviour is found for $\mathrm{S}, \mathrm{P}_{2} \mathrm{O}_{5}, \mathrm{Ba}$ and $\mathrm{Sr}$, with the greater values being found in the deposits formed in the hypogene environment. The greater amounts of $\mathrm{S}$ and $\mathrm{V}$ in the hypogene deposits are explained by the presence of minerals such as alunite (sulphate) and mottramite (vanadate).

The greater content of HREE in the supergene deposits is more easily explained by considering that these elements are fractionated during alteration in the hydrothermal deposits and remain unchanged during weathering, thereby giving greater values in the supergene deposits, where no

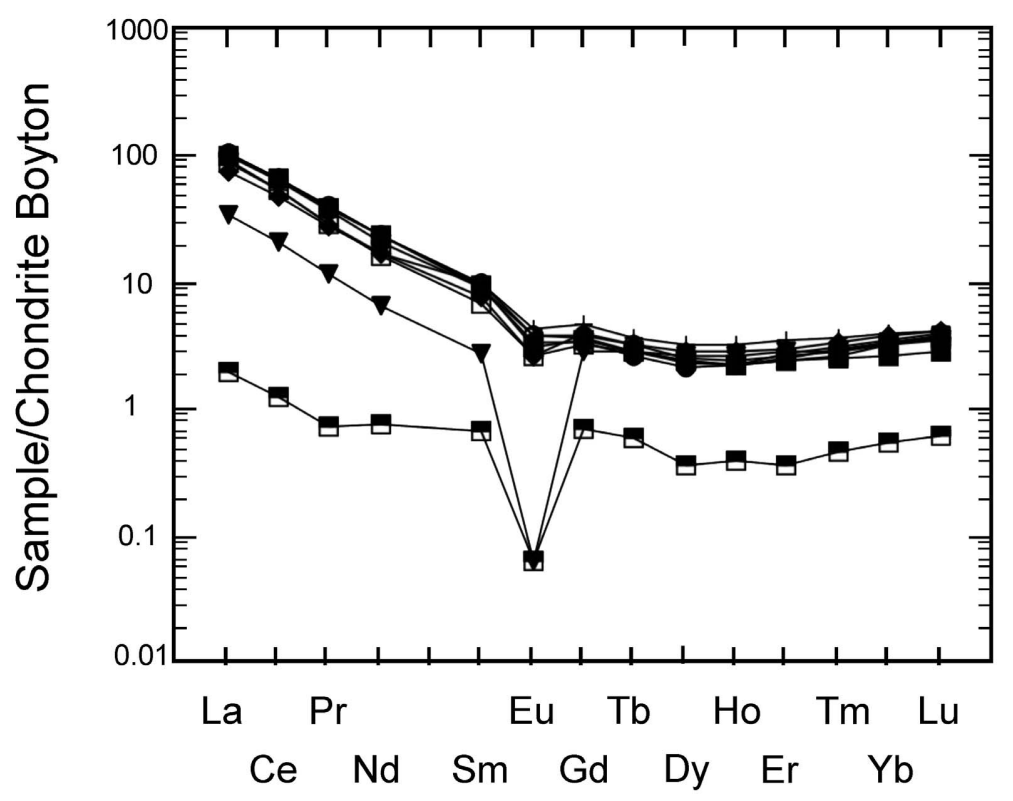

FIG. 11. REE/Boynton chondrite from Adelita deposit. 
fractionation has occurred. Regarding the mobility of elements during hydrothermal alteration, other authors have found different behaviours. In rhyolitic rocks from Yellowstone drill cores, Ti, Al, Fe, Sc, Co, Y, Zr, REE, Hf, Ta and Th remained relatively immobile (Sturchio et al., 1986).

In the advanced argillic alteration zone in Central Iran, $L R E E$ are relatively immobile in the rocks of this zone and depleted in LREE and HREE (Parsapoor et al., 2009). These authors considered that this behaviour may be due to the entry of these elements into the lattice of alunite-jarosite. LREE can in fact substitute for $\mathrm{K}$ in the large-radius cations of the alunite-jarosite formula. Alunite is a common component of the hypogene deposits studied here.

Diaspore can frequently be recognized in kaolin deposits of hydrothermal origin. According to Roy \& Osborn (1954), the boehmite-diaspore transformation temperature is between 270 and $300^{\circ} \mathrm{C}$ at 175-1500 atm water pressure (Marfil et al., 2010).

Thus, using the $\mathrm{O}$ isotope fractionation equation Sheppard \& Gilg (1996) indicated that due to the O and $\mathrm{H}$ isotope composition, the fluids involved in the kaolinization process are of magmatic origin or of superficial origin but isotopically equilibrated with magmatic rocks at magmatic temperatures (Marfil et al. 2005).

\section{CONCLUSIONS}

(1) The mineralogy of the working front varies from an upper zone, where the rock is strongly silicified, stained with iron oxides and carbonated, grades downwards to a kaolinized zone, characterized by a quartz-kaolinite-dickite assemblage with relict lithic particles and a smaller amount of iron oxides to end in the deepest zone where dickite, quartz, scarce associated kaolinite, diaspore and alunite occur.

(2) The host rock is a rhyolitic tuff composed of quartz particles and abundant secondary quartz with iron oxides showing the forms of the primary minerals, mainly mafic minerals and feldspar, and lithic particles. The face is not lithologically homogeneous; some levels consist of lithic tuffs, others of rhyolitic ignimbrites where the size of their components and their porosity vary.

(3) The volcanic glass lenses of ignimbrites occurring at deep levels are the sites with a greatest degree of kaolinization that have been filled with dickite only.
(4) The mineralization is concentrated at the above-described levels since the lithology is the main controlling factor. No structures conditioning the process development are observed.

(5) There is a good correlation between $\mathrm{Al}_{2} \mathrm{O}_{3}$ and LOI content and the degree of alteration. The highest alumina concentration coincides with the greatest kaolin content.

(6) The discriminating diagrams $(\mathrm{Ba}+\mathrm{Sr}) v s$. $(\mathrm{Ce}+\mathrm{Y}+\mathrm{La}),\left(\mathrm{TiO}_{2}+\mathrm{Fe}_{2} \mathrm{O}_{3}\right)$ vs. $(\mathrm{Cr}+\mathrm{Nb})$ and $\mathrm{Zr}$ vs. $\mathrm{TiO}_{2}$ show moderate enrichment in $\mathrm{Ba}+\mathrm{Sr}$ and slight impoverishment in $\mathrm{Ce}+\mathrm{Y}+\mathrm{La}$ contents. The $\mathrm{Ti}$ and $\mathrm{Zr}$ contents, as well as $\mathrm{TiO}_{2}+\mathrm{Fe}_{2} \mathrm{O}_{3}$ relationships, are small (below $1 \%$ ).

(7) The chemical analyses of major and trace elements, textures, mineralogy and the stable isotope values $(\mathrm{O}$ and $\mathrm{D})$ allow the determination of a hydrothermal origin for the Adelita mine.

(8) Mineralization could be related to intrusive andesites cropping out SW of the deposit, which are correlated with the Taquetren Formation of Upper Jurassic age. Furthermore, the mineralizations of fluorite, baryte and polymetals of the region are enclosed in the same lithologic units and are considered to be genetically related.

\section{ACKNOWLEDGMENTS}

The authors wish to thank the CONICET, ANCyPT, CIC from the Province of Buenos Aires, the Geology Department of the Universidad Nacional del Sur and Mr Rodolfo Salomón for their helpful support during the research.

\section{REFERENCES}

Boynton N.V. (1984) Cosmochemistry of the rare earth elements: meteorite studies. Pp. 63-114 in: Rare Earth Element Geochemistry (P. Henderson, editor). Developments in Geochemistry, 2, Elsevier.

Cravero M.F. \& Dominguez E.A. (1999) Origin of sedimentary kaolin in the Neuquén basin, Argentina as determined by oxygen isotopes. Periodico di Mineralogía, 68, 213-222.

Cravero M.F., Domínguez E.A. \& Murray H.H. (1991) Valores $\delta \mathrm{O}^{18}$ y $\delta \mathrm{D}$ en caolinitas, indicadores de un clima templado moderado durante el Jurásico Superior-Cretácico Inferior de la Patagonia, Argentina. Revista Asociación Geológica Argentina, 46, 20-25.

Cravero M.F., Domínguez E.A. \& Murray H. (2001) Genesis and applications of the Cerro Rubio kaolin deposit, Patagonia (Argentina). Applied Clay 
Science, 18, 157-172.

Cravero M.F., Marfil S.A. \& Maiza P.J. (2010) Statistical analysis of geochemical data: A tool: to discriminate between kaolin deposits of hypogene and supergene origin. Patagonia, Argentina. Clay Minerals, 183-196.

Dill H., Bosse R., Henning H. \& Fricke A. (1997) Mineralogical and chemical variations in hypogene and supergene kaolin deposits in a mobile fold belt the Central Andes of northwestern Peru. Mineralium Deposita, 32, 149-163.

Dill H.G., Bosse H.R. \& Kassbohm J. (2000) Mineralogical and chemical studies of volcanic related argillaceous industrial minerals of the Central American Cordillera (western El Salvador). Economic Geology, 95, 517-538.

Domínguez E. \& Murray H.H. (1995) Genesis of the Chubut river valley kaolin deposits, and their industrial applications. Pp. 129-134 in: Proceedings of the 10th International Clay Conference, 1993 (G.J. Churchman, R.W. Fitzpatrick \& R.A. Eggleton, editors) CSIRO Publishing, Melbourne, Australia.

Domínguez E. \& Murray, H.H. (1997) The Lote 8 kaolin deposit, Santa Cruz, Argentina. Genesis and paper industrial application. Pp. 57-64 in: Proceedings of the 11th International Clay Conference (H. Kodama, A.M. Mermut \& J.K. Torrance, editors) Ottawa, Canada.

Domínguez E., Iglesias C. \& Dondi M. (2008) The geology and mineralogy of a range of kaolins from the Santa Cruz and Chubut Provinces, Patagonia (Argentina). Applied Clay Science, 40, 124-142.

Ece O., Schroeder P.A., Smilley M.J. \& Wampler J.M. (2008) Acid-sulphate hydrothermal alteration of andesitic tuffs and genesis of halloysite and alunite deposits in the Biga Peninsula, Turkey. Clay Minerals, 43, 281-315.

Galán E., Fernández-Caliani J.C., Miras A., Aparicio P. \& Márquez M.G. (2007) Residence and fractionation of rare earth elements during kaolinization of alkaline peraluminous granites in NW Spain. Clay Minerals, 42, 341-352.

Gouveia M.A., Prudencio M.I., Figueiredo M.O., Pereira L.C.J., Waerenborgh J.C., Morgado I., Pena T. \& Lopes A. (1993) Behavior of REE and other trace and major elements during weathering of granitic rocks, E'vora, Portugal. Chemical Geology, 107, 293-296.

Hayase K. \& Manera T. (1973) A statistical analysis of experimental data on filling temperature of fluid inclusions in fluorite from fluorite deposits of Patagonia Argentina. Mining Geology, Japan, 23, $1-2$.

Labudía C.H. \& Bjerg E.A. (2001) Grupo Los Menucos. Redefinición estratigráfica del Triásico superior del Macizo Nordpatagónico. Revista de la Asociación
Geológica Argentina, 54, 405-406.

Labudia C. \& Hayase K. (1975) Relaciones entre las rocas y las mineralizaciones de $\mathrm{Pb}-\mathrm{Cu}-\mathrm{Zn}$, fluorita y caolín de los alrededores de Los Menucos, Prov. de Río Negro, Argentina. Sexto Congreso Geológico Argentino, Actas, Bahía Blanca, 3, 69-80.

Mackenzie R.C. (1970) Differential Thermal Analysis Pp. 524-527, Academic Press, New York.

Maiza P.J. (1972) Los yacimientos de caolín originados por la actividad hidrotermal en los principales distritos caoliníferos de la Patagonia. República Argentina. Tesis Doctoral. Universidad Nacional del Sur. Bahía Blanca. Argentina (inédita), 136 pp.

Maiza P.J., Marfil S.A., Cardellach E. \& Zunino J. (2009) Geoquímica de la zona caolinizada de Mina Estrella Gaucha, Provincia de Chubut. Revista de la Asociación Geológica Argentina. 64, 426-432.

Manera T. (1972) La mineralización de los yacimientos de fluorita de la Provincia de Río Negro. Tesis Doctoral, Universidad Nacional del Sur, Bahía Blanca, Argentina. 145 pp.

Marfil S.A., Maiza P.J., Cardellach E. \& Corbella M. (2005) Origin of kaolin deposits in the "Los Menucos" area (Río Negro Province, Argentina). Clay Minerals. 40, 283-293.

Marfil S.A., Maiza P.J. \& Montecchiari N. (2010) Alteration zonation in Loma Blanca Kaolin deposit, Los Menucos, province of Rio Negro, Argentina. Clay Minerals, 45, 157-169.

Pandarinath K., Dulski P., Torres Alvarado I.S. \& Verma S.P. (2008) Element mobility during the hydrothermal alteration of rhyolitic rocks of the Los Azufres geothermal field, Mexico. Geothermics, 37, 53-72.

Papoulis D. \& Tsolis-Katagas P. (2008) Formation of alteration zones and kaolin genesis, Limnos Island, northeast Aegean Sea, Greece. Clay Minerals, 43, $631-646$.

Papoulis D., Tsolis-Katagas P. \& Katagas C. (2004). Monazite alteration mechanisms and depletion measurements in kaolins. Applied Clay Science, 24, $271-285$

Parsapoor A., Kahlili M. \& Mackinzadeh H.A. (2009) The behaviour of trace and rare earth elements (REE) during hydrothermal alteration in the Rangan area (central Iran). Journal of Asian Earth Sciences, 34, 123-134.

Roy R. \& Osborn E. (1954) The system $\mathrm{Al}_{2} \mathrm{O}_{3}-\mathrm{SiO}_{2}-$ $\mathrm{H}_{2} \mathrm{O}$. American Mineralogist, 39, 853-85.

Sheppard S.M.F \& Gilg H.A. (1996) Stable isotope geochemistry of clay minerals. Clay Minerals, 31, $1-24$.

Sturchio N.C., Muehlenbchs K. \& Meitz M. (1986) Element redistribution during hydrothermal alteration of rhyolite in an active geothermal system: Yellowstone drill cores Y-7 and Y-8. Geochimica et Cosmochimica Acta, 50, 1619-1631.

Terakado Y. \& Fujitani T. (1998) Behavior of the rare 
earth elements and other trace elements during interactions between acidic hydrothermal solutions and silicic volcanic rocks, southwestern Japan. Geochimica et Cosmochimica Acta, 62, 1903-1998. van del Marel H.W. \& Beutelspacher H. (1976) Clay and related minerals. Pp. 65-95 in: Atlas of Infrared Spectoscopy of Clay Minerals and their Admixtures. Elsevier, The Netherlands. 